\title{
PENERAPAN HUKUM ISLAM DALAM MASYARAKAT MUSLIM INDIA
}

\author{
Oleh : Djafar Al Katiri
}

\begin{abstract}
ABSTRAK
India sebagai salah satu negaraasia yang memiliki pluralitas Agama (Hindu, Budha, Kristen, Islam dan lain-lain) mengakibatkan pula pluralitas di hidang hukum. Di Anak Benua ini, sebesar umat Islam bermazhab sunni, yaitu bermazhab Hanati dan Syafi'i.

Adat istiadat India yang relative sangat kuat mengalahkan pengaruh hukum negara dalam kehidupan keluarga di India. Akibamya hanyak hal-hal yang bertentangan dengan ajaran Islam yang diabsahkan 1Jlama dipraktekkan masyarakat muslim India. Artinya penunjangan adat istiadat lebih dominan daripada penjunjungan dan pengamalan ajaran Islam.

Kondisi tersebut mendorong pemikir-pemikir muslim India seperti Ahmad Khan. Muh lqbal dan lain-lain untuk melahirkan gagasan-gagasan baru yang lebih dapat memajukan masyarakat muslim India. Digagasnyalah beberapa aspek hukum Islam antara lain hukum publik terutama hukum keluarga. Gagasan ini kemudian diterima oleh masyarakat muslim India karena is terpadukan antara jiss a hukum Islam dengan esensi adat istiadat mass arakat India.
\end{abstract}

Kata Kunci : Negara India, masyarakat muslin: India dun bidang hukum yang diterapkan 


\section{PENDAHULUAN}

Penerapan Hukum Islam di beberapa negara di berbagai negara yang berpenduduk muslim mempunyai pemerintahan tersendiri dan sistem hukum yang satu sama lainnya saling berbeda. Namun demikian setiap yang hendak menerapkan sistem hukum tertentu yang tentunya tidak lepas dari tantangan dari pihak yang tidak menghendaki diterapkannya hukum yang diinginkan oleh penguasa.

Dominasi penguasa atau political will juga sangat berpengaruh terhadap kebijakan hukum suatu negara. Sebab itu implementasi hukum Islam di negaranegara muslim bukan hanya terletak pada banyaknya pemeluk Islam tapi juga ditentukan oleh sistem yang dikembangkan oleh negara yang bersangkutan.

Terdapat pemikiran yang diperdebatkan tentang negara Islam, misalnya saja pendapat Amin Rais yang menyatakan bahwa Islamic State atau negara Islam tidak ada dalam alquran maupun dalam hadits. Oleh karena itu tidak ada perintah dalam Islam untuk menegakkan Negara Islam. Yang sangat signifikan adalah bagaimana negara tersebut menjalankan etos Islam, kemudian mencgakkan keadilan sosial dan menciptakan suatu masyarakat yang egalitarian, yang jauh dari eksploitasi manusia atas manusia maupun eksploitasi golongan atas golongan lain.' Pendapat senada dikemukakan oleh Harun Nasution yang menyatakan bahwa baik istem pemerintahan maupun bentuknya tidak ada ayat di dalam Alquran.

Dalam tulisan ini akan dibahas hagaimana penerapan hukum Islam dalam masyarakat Muslim di India'? Yang berdasarkan literatur yang ada dengan berbagai pendekatan yang dapat memberikan inrormasi yang jelas tentang perkembangan hukum Islam di India. 


\section{PENGERTIAN}

\section{A. Penerapan Hukum}

1. Istilah penerapan hukum merupakan suatu istilah yang hampir semua masyarakat mengetahuinya tapi belum mengerti. Sebab kalimat ini cakupannya luas, maka para sarjana membatasi definisi istilah tersebut. Misalnya Soerjono Soekanto memberikan definisi tentang penerapan hukum dalam pengertian yang luas yang mencakup Lembaga yang menerapkan hukum, misalnya pengadilan, kejaksaan dan kepolisian.

2. Pejabat-pejabat yang memegang peranan sehagai pelaksana atau penegak hukum seperti hakim, jaksa, dan polisi.

3. Segi-segi administratif, seperti proses peradilan, pcngusutan, penahanan.

4. Penyelesaian sengketa di luar pengadilan seperti sengketa perumahan atau rapat-rapat desa pada masyarakat-masyarakat hukum adat.'

Adapun pengertian penerapan hukum secara sempit, A.C. German memberikan pengertian hanya kepada lemhaga-lembaga pengadilan (termasuk pejabatnya), kejaksaan dan kepolisian. ${ }^{4}$

\section{B. Hukum Islam}

Secara etimologi, hukum bermakna "mencegah" yaitu mencegah suatu kezalimans atau mencegah untuk sesuatu kemaslahatan dengan cam bijaksana." Dan secara leksikal herarti menvelesaikan atau mernutuskan suatu urusan dan mencegah seseorang dari apa yang diinginkannya.

Sementara dalam kannis Be car Bahasa Indonesia hukum mempunvai arti

1. Peraturan atau adat yang secara resmi dianggap mengikat. yam.: dilakukan oleh penguasa. pemerintahatau otoritas.

2. Undang-undang, peraturan dan sebagainya untuk mengatur pergaulan hidup bermasyarakat.

3. Patokan (kaidah, ketentuan) mengenai peristiwa (alam dsb) yang tertentu.

4. Keputusan (pertimbangan) yane ditetapkan oleh hakim dalam pengadilan vonis.' 
Sedangkan pengertian hukum menurut para pakar hukum umum adalah peraturan yang bersifat memaksa untuk menentukan tingkah lake menusia dalam lingkungan masyarakat yang dibuat oleh badan-badan resmi yang berwajib.'

Pengertian-pengertian yang dikemukakan di atas, haik dari segi hahasa maupun segi istilah dapat dipahami bat'ma hukum merupakan peraturan atau normanorma yang dengan sadar dibuat untuk menjadi panduan atau pedoman dalam hidup berindividu dan bermasyarakat. Atau secara ringkas dan sederhana. Hukum yang dimaksud disini adalah peraturan atau normauntuk mewujudkan kemaslahatan dan ketentraman hidup manusia.

\section{PEMBAHASAN}

\section{a. Indian Dalam Lintas Sejarah}

India" berawal dari lembah Indus yang merupakan daerah yang subur di anak henua itu. Daerah ini diduduki oleh bangsa Arya. yang selama lehih dari 2.000 tahun mentlembaiwkan peradaban dan memperkenalkan sistem kasta dalam mass arakaL

Pada tahun 327-325 SM, Iskandar Aunt menu erbu India Barat Laut dan pada abad berikutnya, sebagian besar dari anak benua ini dipersatukan di bawah pemerintahan Asoka yang menjadikan Budha sebagai agama Hindu. Pada abad ke $4 \mathrm{M}$, terbentuknya kerajaan Hindu sarw. pertama

Pada abad ke-8, agama Islam diporkenalkan di daerah Sindu oleh pendatam.t. asal Arab. Kontak dengan bangsa kulit putih dilakukan sejak datanganya petualang bangsa Portugis, Vasco Da Gama yang kemudian ikut dalam penyerbuan Portugis ke Goa antara tahun 1526-1570 M, India diperintah Dinasti Mogul. Sementara itu agama Islam terusn berkembam.t. Sejak itu muncul kebudayaan Islam-India dalam berbagai bentuk kesenian dan arsitektur. Salah satu buktinya kemegahan arsitektur Islam-India adalah bangunan Taj Mahal. 
Antara tahun 1746-1763, India menjadi medan pertempuran antara Inggris dan Prancis. Keduanya mencoba memluasai daerah ini dengan Perjanjian Paris tahun 1763. Inggris berkuasa penuh atas walayah ini.

\section{b. Pemikiran Tentang Penetapan Hukum Di India}

Sebagian besar muslim India adalah sunni dan kebanvakan hermashab Hambali dan sebagai bermazhab Syafi'i di Selatan (yang mereka retleksikan hubungan dengan samudera dengan Timur Sekitar 10\% adalah Syi'ah, umumnya Istna Asyariyah (imamiyah). Komunitas Syi'ah yang tidak besar, tetapi penting yakni Ismai'iliyah dipimpin oleh .Aga Khan menjadikan Bombay sebagai tempat tinggalnya pada abad kesembilan belas.

Masyarakat Muslim India secara sosial terbagi oleh afiliasi regional dan linguistik, seperti Bengali, Deccani, Gujarati, Hindustani, Mappila, Oriyya, dan Punjabi. Kaum muslimin secara khas menikah di dalam kelompok status/ keturunan endogamus (di dalam lingkungan sosialnya sendiri), misalnya dilingkungan kerabat, lingkungan sosial, atau lingkungan permukiman), yang bertingkat secara hierarkis. ${ }^{\text {I2 }}$

Adat istiadat yang kuat mengalahkan pengaruh hukum negara dalam kehidupan keluarga di India. Untuk menikah, keluarga gadis harus membayar mas kawin yang mahal kepada keluarga pria. Banyak di antaranya yang melaksanakan perkawinan dengan mahar berutang. Bila ini terjadi, biasanya pengantin wanita akan diperlakukan seperti budak oleh keluarga

Dari ajaran-ajaran tersebut di atas, dalam banyak hal bertentangan dengan ajaran-ajaran Islam yang telah kita kenal, namun para ulama Muslim pada waktu itu menerima baik ajaran-ajaran itu seolahseolah sama seperti ajaran agama Islam dan ini mengakibatkan segala sesuatunya menjadi sulit.

Di antara tokoh yang mempunyal kepedulian terhadap ajaran Islam dan mcmpunyai pengaruh di masyarakat India Muslim adalah Sayyid Ahmad Khan. Dengan melalui pemi kirannya tentang keagamaan, Khan menelorkan pandangannya tentang hukum di India yaitu: 
1. Sayyid Khan menolak anggapan bah- wa Islam berusaha memaksa manusia untuk masuk ke dalam agama Islam melalui syariat jihad. Menurutnya, jihad hanya disyariatkan untuk membela diri dan dalam satu keadaan saja, yaitu ketika orang-orang kafir bertujuan lain seperti pendudukan wilayah, dan bukan bertujuan mengubah agama, maka jihad tidak disyaratkan. Khan menggambarkan pendudukan Inggris terhadap India dan dia hendak mencari dalil pembenaran untuk herdamai dengan Inggris."

2. Menurut Khan, riba yang haram adalah riba yang berlipat ganda, Adapun bunga yang jumlahnya hanya sedikit dalam muamalah perdagangan sekarang dan yang terdapat dalam perbankan, bukanlah riba yang diharamkan.

3. Khan menempatkan hukum waris di bawah hukum wasiat, karena penye- butannya digabungkan antara ayat waris dan wasiat. Menurut Khan tidak ada nasakh 'penghapusan' di dalam alquran, Berdasarkan hal tersebut, Khan memandang hendaknya harta si mayyit dibagi berdasarkan wasiatnya, dan harus dilaksanakan sebagaimana mestinya tanpa kendali apapun. Dan tidak mengakui hadis-hadis yang membatasi wasiat maksimal hanya sepertiga harta, atau hadis yang melarang berwasiat kepada salah seorang pewarisnya.

4. Khan menegaskan bahwa pada dasarnya Islam mengatur pernikahan dengan satu wanita, sedangkan poligami merupakan pengecualian. Dan alquran telah menjadikan keadilan sebagai persyaratan poligini. Berhubung adil itu tidak mudah sebagaimana disebutkan dalam alquran sendiri, maka poligami tidak diperbolehkan kecuali dalam keadaan yang jarang dan harus terbatas pada kondisi pengecualian.

5. Dalam masalah had (hukuman), Khan menolak hukum rajam bagi penzina. Khan bersandar pada dua dalil: 
1. Rajam tidak disebutkan di dalam alquran hal im menurui Khan cukup. sebab menurut Khan hadis tidak bisa dijadikan sebagai hujjah.

2. Seandainva kita harus menerima hadis-hadis tersehut hanya menceritakan kehiasaan yang tersehar pada masa itu karena mengikun Yahudi.

6. Tentang hukuman huang bagi perampok, sekarang im tidak mungkin dilaksanakan. Sebab, apa manfaatnya dikeluarkan seorang pent ahat dan negerinya ke negeri lain sementara dl sana melakukan kejahatan dan pengrusakan juga? Potong tangan dan kaki merupakan hukuman yan2 ditetapkan pada masa awal, karena pada saat itu beim ada penjara. Adapun sekarang harus dihentikan pelaksanaan hukum yang mengerikan tersebut, Yang hertentangan dengan peradaban. ${ }^{\prime \prime}$

Pembaruan penerapan hukum juga digelindingkan oleh lqbal terdapat beberapa hal :

1. Prinsip-prinsip hukum dalam alquran berdimensi luas, dan jauh dari menjadi penghalang bagi pemikiran manusia atau menjadi penghalang aktivitas hukum. Sesungguhnva generasi pertama dari kalangan Fuqaha telah bersandar pada prinsipprinsip perkembangan ini. Dan mereka telah mengeluarkan sejumlah sistem hukum, padahal kesempurnaan mazhabmazhab mereka hanyalah penafsiran dan istinbath hukum yang mereka lahirkan merupakan kalimat akhir. Berhubung kondisi telah berubah, dan dunia Islam sekarang ini telah dipenuaruhi oleh kekuatan baru yang dihadapmva, maka lqbal berpendapat balm a kebcbasan berpikir dalam Islam yang diseruhkan oleh generasi sekarang vaitu tentang penafsiran prinsip-prinsip hukum demean mengi.tunakan penafsiran baru yang mengaeu pada pengalaman mereka dan kondisi yang tidak tetap dalam kehidupan, benar-benar memungkinkan 
2. Menurut Iqbal bahwa ijma termasuk dalam pemikiran hukum yang terpenting dalam Islam lqbal memndang, pentingnya memindahkan hak ijtihad dari perseorangan kepada suatu lernbag-a hukum Islam, karena hal itu merupakan satusatunya bentuk yang paling mungkin untuk mewujudkan ijma pada masa sekarang ini. Menurut lqbal bahwa sate-satunya cara untuk mengurangi terjadinya kesalahan dalam penarsiran hukum adalah memperbaiki sistem pengajaran hukum dan memperluas jangkauannya."

Berdasarkan pemahaman tersebut, lqbal menveru dunia Islam agar berani tampil untuk menyempurnakan pembaruan yang dinantikannya, yang aspek terpentimmva adalah menyesuaikan hukum Islam dengan kondisi kehidupan modern. Namun lqbal menambahkan beberapa Dan hal ini merupakan sebaik-baik tulisannya dalam pasal ini :

"Dengan senang hati kami menyambut pembebasan berpikir dalam Islam baru, Namun perlu ditegaskan bahwa saat munculnya pemikiran-pemikiran bebas dalam Islam. merupakan saat yang paling tersembunvi di dalam sejarah. Di antara dampak buruk dari kebebasan berpikir adalah kecenderungan menjadi faktor penyebab kenterdsotan. Di samping itu para tokoh pembaruan dan politik memiliki semangat untuk membebaaskan pemikiran, namun terkadang melampaui batas-batas pembaruan yang benar jika tidak ada pengendali terhadap berkobamya api semangat mereka.

Sesungguhnya patut diingat bahwa keadaan saat ini bukanlah merupakan hasil dari terjadinya perubahan yang sempurna, karena masih mengandung unsur-unsur yang cenderung tetap di alas keadaan lama. Bukanlah merupakan kesanggupan umat untuk mengingkari masa lalunya secara sempurna, karena masa lalulah yang mempengaruhi pribadinya pada masa sekarang." 


\section{Kesimpulan}

1. Islam dengan tegas melarang perbudakan.

2. Transaksi perdagangan, pinjaman serta perdagangan internasional, jika itu mencakup pembayaran bunga, tidaklah dianggap riba.

3. ljma sangat dibutuhkan dalam sistem penetapan hukum. 


\section{CATATAN KAKI :}

1. M. Amin Rais, tidak ada negara Islam, dalam Ahmad Syafi'I Ma'arif dan Adi Sasono (Kata Pengantar). Thlak 4(1) $t$ Negara Islam (Suraisurat Politik Nurcholis Mac jid-Muluanmad Room), (Jakarta Djembatan, 1977). h XXII

2. Harun Nasution, "Islam dan Sistem Pemerintahan Sebagai Yang Berkembang Dalam Sejaran", Dalam, Studio

Nomor 17 tahun VIII, Juli 1985). h. 12

3. Achmad Ali, Mengemhara di Belantara Hukum ,(Ujung Pandang. 1.ephas, 1990, h 214.

4. Ibid.

5. Abu Husain Ahmad bin Faris bin Lakariah, Ala :jam al- Nlauzyo alLugha h. Bairut: Dar al-Fikr. 1997), h. 277.

6. Allamah Al-Ragih al-Isfahan. Mirtrado/al-/a.: al-Qur'an, (Bairut Dar al-Qalam. 1996), h 249.

7. Departemen Pendidikan Dan Kehudayaan Republik Indonesia, Kahno Brsar Rolhort Indonesia, (Jakarta: Pustaka, 1994), h 360.

8. C.S.T. kansil, Pengantar dan Tata Hukum Indonesia. (Jakarta: Balai Pustaka, 1989), h 38.

9. India adalah sebuah negeri yang herpendiiduk 759.000.000 jiwa, 10";, di Antaraiiva adalah muslim ekspansi ke India bermula pada keberhasilan penaklukan hangsa Arab atas wilayaheilayah Sind di bawah pimpinan Muhammad ibn Qsim pada tahun 93 IA/ 712 M Islam tersebar semakin luas di India oleh invasi Ghaznawi, khususnya pada masa kepemimpinan Mahmud Ghasnah (w 4221-F1030M), selanjutnya Islam berkermbang semakin kokoh di Punjab dan Kasmir. Pada masa kekuasaan kesultanan Delhi (602-962H/1206-1555M, dan pada masa kekuasaan Moghul (932-1274H/1526-1885M pemerintahan Islam di India mencapai masa kcjayaan. Cyril Glasse, Ensiklopedi Islam, (Jakarta: Raja Grafindo Persada, 1999), h 169. 
10. Tim Penyustm. E 17.1 iklopedia Nasional Indone.Nia. (Jakarta: Delta Pamung,kas, 1997), h. 58.

11. Ibid

12. John L. Esposito. Ensiklopedi Oxford Donut Islam Alodern_ Mid 2, (Bandung: Mizan 2001). h. 298.

13. Ensiklopedi Nasional Indonesia. Op. cit, h 57.

14. Busthami Muhammad Sa'id. Maflnnrr Tajdieluddin, diter oleh Ibnu Marjan, Gerakan Pembaruan Agama: Modernisne dun Taphothaldin. (Jakarta: Wacana Lazuardi Amanah, 1995), h 140.

15. Ibid, h 141. I 6. Ibid.

16. Ibid.

17. Ibid, h 154-155. 